\title{
DOI: http://dx.doi.org/10.18616/portugal01
}

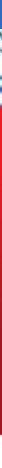

(Evaldo Balbino)

Nestas terras e além delas,

os pés caminham, caminha

a voz humana mui vária.

São tantas almas, desejos,

e os corpos são naves

navegando mares.

Os corpos são aves

nadando o oceano

- esta imensa ponte.

As águas unem fados

de cristos humanados

e pés andando em ondas.

Aqui mesmo onde,

nas terras brasis,

se multiplicam cores. 
Se multiplicam línguas

desdobrando os panos

e os mil paladares.

Aqui mesmo migro, vagueio entre falas

se namorando várias.

Arapucabiboca

carioca caipora

curumimjururu.

Acarajé farofa

fubá bobó moqueca

quitute de se comer.

Açafate acéquia

achaque abajur

de lâmpada bege.

Ária arpejo sonata

trêmulo soneto

e esta minha serenata.

Efêmero íncola

na valsa no verso

de línguas irmãs. 
Navego entre palavras

me cingindo amorosas

por não me serem só.

Sigo entre montanhas

e as livres planuras

de gentes e saberes.

Em cerrados e caatingas

ramificam-se olhares,

entrebeijam-se sabores.

Vivo este terreno

onde bocas emaranham

cultivos e culturas.

Do mesmo modo ouço

além, do outro lado

dessa líquida ponte,

As vozes portuguesas

se estendendo longe,

me osculando a fronte.

Banheiro casa de banho

café da manhã calcinha

bonde cuecas elétrico. 
Acólito coroinha

celular telemóvel

aluguer de mágoas fado.

Ponto de liga trem

pano de prato/loiça

belo desenho de moça.

Time equipa tricô

comboio xícara chávena

onde juntos solvemos.

A última flor do Lácio,

a língua portuguesa,

a mesma língua vária.

O oceano não separa

em sua imensa seara

o que o tempo ajuntou.

Belo Horizonte, 11 de setembro de 2018. 